\section{SPIROCHÆTA PALLIDA (SPIRONEMA PALLIDUM) IN SYPHILIS.**}

BY THEODORE SHENNAN, M.D. EDIN., F.R.C.S. EDIN., SENIOR PATHOLOGIST, ROYAI, INFIRMARY, EDINBURGH ; LECTURER ON PATHOLOGY AND BACTERIOLOGY, SCHOOL OF MEDICINE OF THE ROXAL COLLEGES, EDINBURGH, ETC.

SyPHILIS has always been regarded as a disease of an extraordinarily infective or contagious character, hence it is not remarkable that a contagium rivum has long been suspected to play the principal rôle in its etiology. Krzysztalowicz and Siedlecki ${ }^{53}$ point out that in the sixteenth century Kirscherius and David Abercromby claimed a "contagium animatum" as its cause and Deidier (1723) spoke of "animaloula numerosa," these terms no doubt being used without much appreciation of what they imply in more modern times.

The list of causes assigned of late years is a formidable one: bacteria of ali kinds, cocci, bacilli including the ubiquitous pseudo-diphtheria bacillus, and Lustgarten's bacillus which for a time had an unsettled reign as the "syphilis bacillus" but which is now recognised to be probably identical with the smegma bacillus. Lassar ${ }^{44}$ states that more than 25 causes of syphilis have been described during the last three decades. Niessen in 1899 described a bacillus not stained by Ziehl's method but Gram-positive. This inoculated into rabbits produced ulceration, swelling of lymphatic glands, and lesions of the central nervous system in which a prominent histological feature was a peri-arteritis analogous to that found in syphilis in man. Kuznitzky described comma-shaped bodies and bodies like spirilla. Lostörfer described small refractile bodies in the blood of syphilitics which became less numerous during mercurial treatment. Winckler found peculiar spherical bodies in syphilitic local lesions and in glands.

Several authors have believed that the causal agent is protozoal-e.g., Hügel, Horand ${ }^{1}$ with his "hémoprotiste," Holzhaüser ; lately Schüller ${ }^{38}$ and Stassano, ${ }^{4}$ the last-named figuring protozoa in all stages of development. Still more recently Siegel ${ }^{3} \pm$ has described the minute cytorrhyctes luis, a flagellated protozoon, and he claims that it occurs constantly in syphilitic lesions. This has not been found by more than one or two independent observers and Metchnikoff says that Siegel's descriptions and figures are enough to prove to him that this body is of no importance if it is not an artefact.

Neisser ${ }^{103} 3$ also discusses this question. He states that Siegel's bodies can be found in normal blood and emphasises the fact that he claims to have produced syphilitic lesions in rabbits, which are generally considered to be immune from syphilis. To prove the point Neisser inoculated several rabbits with syphilitic material and then after several weeks inoculated monkeys with portions of their kidneys. No lesion resulted. His experiments are strongly suggestive but not absolutely convincing. I have seen peculiar rounded bodies in films from indolent buboes, like those described by Winckler, and which are possibly degenerated cells. They usually stain bluish with Giemsa's solution. More interesting than these are loopshaped bodies, staining a bright pink with Giemsa's solution, and found in the same situations (see Case 17). The opinion has been expressed by several, including Lassar, $4 \pm$ that some of these bodies-e.g., Siegel's-may turn out eventually to be related developmentally to the spirochætæ of Schaudinn and Hoffmann. Krzysztalowicz and Siedlecki have seen similar loop-shaped bodies in glands. ${ }^{53}$

The Imperial Board of Health in Berlin commissioned Schaudinn, a biologist already well known by his researches on the malaria parasite, trypanosomes, \&c., to investigate Siegel's results, and he requested Hoffmann, a skilled syphilologist, to assist in the research. In a very short time they announced the discovery of spirochæ $\aleph^{t}$ in primary and secondary syphilitic lesions. It is a curions fact that Siegel and his cytorrhyctes are not, so far as I can find, referred to at all in the papers they have published..$^{5} 11$

The possibility of spiral forms having a causal relationship

* An abstract of this paper was read before the Edinburgh Medico Chirurgical Society on Jan. 17th. The "superior," or raised, numeral occurring throughout the article refer to the bibli igraphy at the end of the second part. to syphilis was first hinted at by Donné in $1837 . .^{88} \mathrm{He}$ found and figured forms to which he gave the name "vibrio lineola." Neumann refers to this observation in his textbook on syphilis (1899). Possibly the vibrio lineola may correspond to what is now named "spirochæta refringens."

Metchnikoff and Roux in 1902 discussed the possibility of spirilla smaller than those of Obermeier or those discovered in a disease of fowls in Rio de Janeiro being the cause of syphilis and came to the conclusion that the agent was more probably a non-motile microbe. ${ }^{98}$ Since Schaudinn and Hoffmann announced their discovery Bordet and Gengout ${ }^{43}$ state that in 1902 they had seen these same spirochætæ in a case of syphilis, but as they failed to demonstrate them in other cases they concluded that they were of no practical importance.

Literature.-Schaudinn and Hoffmann ${ }^{5}$ first describe two forms of spirochretre occurring in syphilitic lesions not only at the surface but also in their depths and in the lymph glands connected. One form is delicate (spirocbrta pallida) 4-10 $\mu$ long with an average length of $7 \mu$, less therefore than the ordinary spirochætæ of the mouth and those of relapsing fever. They remain alive for several hours in physiological salt solution. They were found in entire and ulcerated skin papules, condylomata, hard chancres, and glands, the age of which varied from five and a half weeks to six months. With the spirochæta pallida they sometimes found a coarser form (spirochæta refringens), particularly in ulcerated lesions. In later papers ${ }^{6} 7^{812}$, one of which ${ }^{6}$ was given by Schaudinn in opening a discussion on the subject before the Berlin Medical Society, more details are given as well as the distinguishing characteristios of the two forms of spirochætæ. They describe the spirochæta pallida as extremely delicate, weakly refractile, vigorously motile; staining ro: e-pink with Giemsa's stain; requiring powers of 800 and upwards to demonstrate ; long, very thin, and filamentous, spiral or corkscrew-shaped, with pointed ends. Its length varies from 4 to $14 \mu$; its breadth is difficult to gauge, being at most about $0.25 \mu$; the spirals number 6 to 14 These are abrupt, narrow, regular, and deep. It progresses by rotating on its long axis and when at rest shows undulatory movements in its whole length, suggestive of the play of a vibratile membrane. The staining characters distinguish it from all other spirochætæ and also from spirilla, these staining of a bluish or purplish colour by Giemsa's method. The spirochæta refringens is flatter and the spirals are wider, giving it a wavy or undulating form. It is thicker, stains more deeply, and usually has truncated ends. It never occurs in the depths of syphilitic lesions, in glands, or non-ulcerated papules. It possesses a vibratile membrane.

Schaudinn, as a result of his previous studies on similar parasites in the stone owl (athene noctua), placed spirochætæ amongst the protozoa-group flagellata-and no longer with the bacteria. Schaudinn and Hoffmann found spirochæta pallida constantly in surface lesions and also in all available cases in the indolent buboes, in the latter unaccompanied by other micro-organisms. Schaudinn demonstrated them in blood obtained by puncture of the spleen during life.

Buschke and Fischer ${ }^{15}$ demonstrated spirochæta pallida in the spleen of a child who died from con enital syphilis and also ${ }^{16}$ in blood films taken from the same infant during life. Non-syphilitic children gave negative results.

Metchnikoff and Roux had already ${ }^{18}$ succeeded in infecting monkeys with syphilis and now ${ }^{19}$ reported that in four out of six cases they found spirochætæ corresponding to spirochæta pallida unaccompanied by other forms. They found them, moreover, in four out of six cases in man in recent scrapings of secondary papules and also in one case of congenital syphilis. In control cases (psoriasis, scabies, acne, \&c.) the results were negative.

Raubitschek ${ }^{23}$ and Frosch ${ }^{21}$ detected the spirochæta pallida in the circulating blood in secondary syphilis.

Wechselmann and Lôwenthal, ${ }^{26}$ using the "ultra-microscope," described the spirochæta as made up of several segments and noticed what they took to be a nucleus.

Levaditi ${ }^{27} 2829$ found typical spirochætæ in the contents and bases of the bullæ of pemphigus in a congenitally syphilitic infant three months old and also in the spleen, lungs, and particularly the liver of the same case. He considers congenital syphilis to be a spirillosis of the newly born.

Salmon ${ }^{31}$ and Hoffmann ${ }^{10}$ confirm this result in the pemphigus of congenital syphilis. 
Jacquet and Sevin ${ }^{33}$ found spirochæta pallida in secondary lesions but failed in 23 tertiary lesions examined.

Kraus ${ }^{31}$ insists on $t^{\prime}$ e necessity for making a considerable number of preparations, as the spirochætæ are often very irregularly and unequally distributed. He observed that in a chancre kept 12 hours on ice, no spirochæetæ could be demonstrated, although they were visible in fresh preparations. He has never found spirochata pallida in controls.

Volk, ${ }^{3.5}$ in the chancres and papules in 14 syphilitics, found the parasite in the great majority. The results were positive in only one out of 14 syphilitic glands and were negative in the glands connected with 17 control, non-syphilitic lesions.

Hoffmann, ${ }^{1 C}$ in a paper already referred to, notes that Schaudinn and he found spirochæetæ pallid $x$ in non-ulcerated skin papules far away from the genitals (breast and back).

Horand ${ }^{1}$ refers to his published papers describing a " hémoprotiste, agent pathogène de la syphilis," and believes that Schaudinn's parasite corresponds to one of the involution forms of this " hémoprotiste."

M. Schüller, ${ }^{36}$ in a review of Schaudinn and Hoffmann's paper on the Occurrence of Spirochrta Pallida in Indolent Buboes, ${ }^{7}$ doubts whether there is any etiological relationship at all. The parasite may have entered through the ulcerated surfaces. Moreover, bacteria have been found in glands in connexion with non-ulcerated lesions and also in congenital syphilitic lesions. He thinks that the presence of spirochæta pallida in experimental lesions in monkeys does not clear up the question, but simply shows that along with the cause of syphilis the spirochætæ and any other bacteria present have been transferred. He also criticises the technique employed and cannot understand Schaudinn's grounds for placing spirochætæ amongst the animal parasites.

Vuillemin ${ }^{3 T}$ proposes the name "spironema" for spirochætæ with sharp ends. The "spirochæta pallida" would thus become the "spironema pallidum."

$\mathrm{McWeeney}{ }^{3 \mathrm{~s}}$ found spirochæta pallida in nine primary and secondary cases, not in a tertiary ulcer of the palate or in a non-ulcerated, muco-purulent vaginitis. He thinks it possible that tertiary lesions and congenital forms of syphilis may be due to a chronic intoxication caused by absorption of metabolic products of the spirochætæ.

C. Fraenkel ${ }^{0}$ writes enthusiastically in support of Schaudinn and Hoffmann and goes further than these authors, claiming that there is no doubt that spirochrta pallida is the cause of syphilis. He found that organism in six varied cases of syphilis.

Vilh. Jensen ${ }^{41}$ found spirochreta pallida in a hard chancre and the associated gland and in several entire and ulcerated papules in the region of the genitals. They were not found in control cases, non-syphilitic. He believes that the true cause of syphilis has been found.

Bordet and Bayet ${ }^{42}$ consider this the most serious attempt yet made to unravel the etiology of syphilis. Bayet found spirochæta pallida in the spleen of a congenitally syphilitic infant. Lassar ${ }^{41}$ discusses the discoveries of Siegel and Schaudinn and reminds his readers that during the last three decades more than 25 causes of syphilis have been described.

K. Herxheimer and H. Hübner ${ }^{15}$ demonstrated spirochæta with Giemsa's stain and also with Nilblau B.R. or Capriblau. They examined 18 cases and in 15 of these they found spirochæta pallida but only in extremely small numbers in some cases. In two of the remaining cases the diagnosis was between soft sore and syphilis. In these no spirochætæ pallidæ were found and the subsequent course of the illness justified that result. They claim to have seen a spirochreta in a section cut in paraffin and stained with Nilblau. Examinations of blood, lymph glands, and congenital syphilitics proved negative.

Kiolomenoglou and von Cube ${ }^{49}$ confirmed the fact of the occurrence of spirochreta pallida in syphilitic lesions but they considered it still more important to ascertain whether it was always absent from non-syphilitic lesions. They exercised the greatest care in making and staining their preparations. They found spirochæta pallida in a collection of syphilitic cases, in an inflamed phimosis in which there may have been a masked primary sore, in gonorrhceal pus from Bartholini's gland, in balanitis, in pus from a scrofulodermatic abscess, in an ulcerating cancer, and in condyloma acuminatum. They found forms intermediate between spirochæta pallida and spirochæta refringens and corresponding to neither. Schaudinn, to whom their preparations were submitted, confirmed their opinion that there were more than two species of spirochætæ present, but with Hoffmann declares that all occurring in non-syphilitic lesions, can be, either morphologically or tinctorially, distinguished from spirochæta pallida. Still, one feels that they do not conclusively dispose of all the objections of Kiolomenoglou and von Cube.

Hoffmann" with Mulzer found spirochætæ in ulcerated carcinomas of the cervix and skin very similar to spirochæta pallida and which they could not with confidence distinguish from it. In a later paper ${ }^{12}$ Hoffmann states that those found in carcinomata have blunt ends.

Babes and Panea ${ }^{50} 51$ found spirocbrotæ palliãæ in two out of three cases of congenital syphilis, in one case occurring especially abundantly in the suprarenals. They were found where characteristic histological changes were best seene.g., the liver ; but in the suprarenal such changes were not so marked, though the organisms were in great numbers.

Galli-Valerio and Lissueur ${ }^{52}$ emphasise the fact tbat spirochreta pallida has been found in closed lesions-e g., indolent buboes. They detected it in condylomas and in mucous plaques in six out of ten syphilitics. They failed in two cases undergoing treatment and in a tertiary case, also in a hard chancre and gland connected therewith, and in the cerebro.spinal fluid of two cases.

Krzysztalowicz and Siedlecki (Krakow) ${ }^{53}$ give an interesting historical retrospect of the search for the cause of syphilis and furnish full references. They describe several delicate shapes in the fluid from excised glands, very motile, at first oval but on longer observation elongating at both ends as if sending out processes in one line. They describe apparent longitudinal splitting up of spirochætæ similar to what is seen in trypanosomes. They figure coarse spirock retæas pallidæ, which one should rather incline to place under the "refringens" class. They state that the numbers of spirochæ! pallidæ increase in proportion to the distance from the surface.

Thesing, who at the first discussion in the Berlin Medical Society suggested that the spirochætæ came from the staining fluid, believes 5455 that they are harmless saprophytes occurring secondarily in syphilitic lesions and penetrating to glands from the surface. He thinks, moreover, that such a flexible body as spirochæta pallida should not be tied down to the constant possession of steep spirals.

Ploeger ${ }^{62}$ discusses the morphology and ajevelopment of spirochætæe and distinguishes them from spirilla by the flagella which the latter possess. He suggests that all spiro. chætæ the spirals of which measure about $1 \mu$ or less should be placed with spirochæta pallida, and those with more than $2 \mu$, with spirochæta refringens. He describes short forms with a terminal knob. He found the spirochæta pallida in two chancres, one gland, and three anal and one vulvar papule. One cannot be certain what proportion this was of the cases examined. Some of the forms seen in films from glands were $20 \mu$ long. He, as well as Rille ${ }^{58}$ and Mulzer, ${ }^{70}$ has seen some apparently attached to red blood corpuscles and the suggestion is made that these cells may convey the parasite throughout the body.

Spitzer ${ }^{31}$ demonstrated the presence of the spirochæta pallida in six primary sores; in seven secondary cases even after prolonged treatment; in one ulcerating case of eight years' duration (Spätform), with infiltration of the nose, lips, and lower lid; and in a case, 12 years after infection, in a gumma of the scalp. In this case only one spirochrta was found in three or four preparations. He never found spirochretre in the blood or in a series of non-syphilitic conditions.

Rille ${ }^{18}$ refers to the behaviour of the spirochæta pallida in physiological salt solution and in glycerine. He refers to Bordet's and Gengout's observation of these spirochætæ in 1902 and says that he himself saw them in 1894. He had lately positive results in three primary lesiors in the male, in one in the female, and once in an inguinal bubo and condyloma latum. He thinks that the possibility of the spirochæta pallida being a morphological variant of the spirocheta refringens should be excluded. He refers to Donné's discovery of "vibrio lineola" (1837) and his belief that it was the cause of syphil:s.

Noeggerath and Stachelin ${ }^{6 i}$ found the spirochæta pallida in syphilitic blood by the following method. They take one cubic centimetre of blood from a vein, mix with ten cubic centimetres of $\frac{1}{3}$ per cent. acetic acid in water, centrifugalise, and examine the deposit.

Neumann ${ }^{81}$ found the spirochæta pallida in six cases, two of which had been treated.

Queyrat and Joltrain ${ }^{81}{ }^{82}$ found the spirochæta pallida in 
a quatter of their cases ( 31 in all) of hard chancre but never in non-syphilitic lesions. They think that it must have a diagnostic significatic $n$.

Jesionek, ${ }^{63}$ discussing Ploeger's paper, ${ }^{62}$ refers to the conclusions of Kiolomenoglou and von Cube and maintains that their results are correct. He refers also to the intermediate forms and suggests that spirochæta pallida and refringens may be developmental stages of one and the same organism. This was before spirochætæ were found in the blood.

R. Kraus and Piantschoff ${ }^{65}$ contribute an important paper. They find that spirochæ' $x$ disappear from excised chancres when kept and quote Metchnikoff and Roux, who found that after six hours an excised lesion was useless for the demon. stration of spirochætæ. This is interesting in view of the generally accepted clinical fact that the syphilitic virus remored from the living body or after death soon degenerates. They found the spirochæta pallida in 32 out of 37 hard chancres; in the negative cases the lesions were necrotic, purulent, or the material was delayed too long in transit. 18 out of 25 papules gave positive results. In the lesions in four macacus monkeys spirochæłæ pallidæ were found. Like Ploeger, they saw short forms with from three to four spirals, with spherical bodies either attached to one end or free. They suppose that they are involution forms analogous to those seen in Pfeiffer's phenomenon in the case of the cholera vibrio. On making sections of an excised sore parallel to the surface and examining films from each they found that true spirochæ!æ pallidæ increased in numbers as they went deeper.

Levaditi and Petresco ${ }^{30}$ find that the spirochætæ pass readily and in considerable numbers into blisters produced by cantharides on the surface of syphilitic lesions. They have been successful in this way in demonstrating spirochætæ pallidæ in roseolar eruptions.

Bandler ${ }^{66}$ details the methods of staining he has found successful.

Leiner ${ }^{67}$ found spirochæta pallida in congenital syphilitic pemphigus. Lannois ${ }^{68}$ saw Schaudinn's spirochæta associated with Vincent's bacillus fusiformis. Almkvist and Jundell ${ }^{69}$ found the spirochæta six times in seven cases, but never succeeded in films from glands, blood, or non-syphilitic lesions.

Mulzer ${ }^{70}$ demonstrated spirochæta pallida in films from 20 out of 22 cases. One of the failures was from a roseolar eruption. He occasionally found them in cells probably of endothelial nature. Some showed a spindle-shaped swelling between the middle and terminal thirds. In one case he found a mesh-like agglomeration of from 20 to 40 individuals. No spirochætæ pallidæ were found in normal smegma in five women and ten men. He quotes Csillag's negative results in three men and 16 women. Rona found spirochæet in six out of 20 healthy women and in three out of 18 healthy men. Menge-Krönig füund them also in women. In 21 out of 29 patients with non-specific ailments Mulzer found no spirochætæ.

Nigris ${ }^{71} 72$ claims that he found the two varieties together in the blood. Hoffmann, ${ }^{1 \pm}$ who saw the preparations, denies that this is the case.

Scholtz ${ }^{73}$ doubts whether spirochæta pallida, even when occurring in great numbers in syphilitic lesions, has an etiological significance. It may be that the conditions produced are specially favourable for that organism to grow and develop. He found an apparently undoubted spirochæta pallida in a condyloma acuminatum. In primary and secondary lesions be had 19 positive and 11 negative results and two positive and one negative result in congenital syphilis. He failed to find spirochætæ in roseolar blosd in two cases, in buboes in two cases, and in teriary syphilis in four cases In 12 controls the results were negative. Hoffmann ${ }^{1 \pm}$ examined the film from the condyloma acuminatum and averred that only spirochæta refringens was present.

Grouven and Fabry ${ }^{7 \pm}$ had positive results in 14 out of 20 primary and secondary lesions, in two cases of congenital syphilis, and in syphilitic blood, following the method of Noeggerath and Staehelin. ${ }^{81}$

Rille and Vockerodt ${ }^{59}$ in 14 syphilitios found manifest spirochætæ pallidæ in 22 different lesions. They failed in roseolar blood and syphilis hæmorrhagica neonatorum. With Ploeger they think that the spirochætæ have a relationship to the red blood corpuscles. Thoy found thern in a case seven or eight years old.

Sobernheim and Tomasczewski ${ }^{75}$ in 50 primary and secondary syphilitics found spirochæta pallida in all cases.
In eight tertiary syphilitics they failed. In some of the positive results spirochætæ were very scanty and found only after prolonged search. They doubt whether they are actively motile. They consider that spirochreta pallida is the cause of syphilis.

Siebert ${ }^{76}$ has found spirochætæ which agree strictly with the type "pallida" indicated by Schaudinn and Hoffmann only in syphilitic lesions. He refers to the difficulties of distinguishing them morphologically and points out that there is no analogous disease in which the number of the causative organism bears no relation to the intensity of the reactions. Here the organisms are generally scanty. $\mathrm{He}$ found spirochætæ which in delicacy could not be distinguished from the spirochrta pallida. $\mathrm{He}$ is evidently not wholly convinced. His results are positive in 52 out of 66 cases of primary, secondary, and congenital syphilis ; negative in six indolent buboes, in seven tertiary cases, in blood, and spinal fluid. He confirms the observations of Klingmüller, Baermann, and Metchnikoff that the syphilitic virus cannot pass through a porcelain filter. His results were also negative in 46 control non-syphilitic cases.

Flügel ${ }^{77}$ examined 28 cases, in all being successful. Some showed only one spirochæta pallida after very prolonged search. In the liver of a congenitally syphilitic child he found only one spirocbæta. They were frequently in relation to red blood corpuscles (cf. Ploeger, Rille, Scholtz, and Roscher). He found them in the blood by the method of Noeggerath and Staehelin.

Brönnum and Ellermann ${ }^{78}$ found spirochæta pallida in two cases of congenital syphilis.

Roscher ${ }^{79}$ produces a very long, complete, and carefully detailed paper in three parts. Of primary affections, genital and extra-genital, 31 gave positive results and one was negative. In 16 there were no general evidences of syphilis, but in 11 of these which continued under observation secondary signs appeared later. 30 buboes gave positive results and eight were negative. 55 moist papules were positive, three were negative, of which one had been treated, one was dry, and one was not scraped deeply enough. 34 non-ulcerated papules gave positive results, and six were negative. Plaques on the tonsils were 14 times positive, once negative. Two plaques on the tongue and 14 papules on the lips or at the angle of the mouth were positive. In these, coarse spirochætæ, in addition, were regularly found. Impetigo of the scalp gave four positive results, and blood three positive and three negative results. He never found coarse spirochætæ in glands or in closed efflorescences. In all, 206 syphilitic lesions were examined, 184 with positive and 22 with negative result.

Schaudinn ${ }^{9}$ contributed another paper on this subject in October. He found spirochæta pallida constantly in 70 cases and also in tertiary lesions as granular resting forms. He raises the number of spirals in the typical form to 10-26. He states that the new Giemsa stain is the best for its demonstration and advises preliminary momentary fixation with osmium vapour. He claims that the parasite possesses flagella and possibly a vibratile membrane, though this is not yet clearly demonstrable. As these characters separate spirochæta pallida not only from spirochætæe and spirilla but from all other related forms he adopts the name spironema suggested by Vuillemin. ${ }^{37}$

De Souza, jun., and Pereira ${ }^{80}$ found spirochæata pallida in nine primary and secondary cases and in one congenitally syphilitic infant with pemphigus. Cultures in human blood with 5 per cent. each of sodium citrate and sodium chloride were negative.

Reischauer ${ }^{83}$ found spirochæta pallida in the liver, spleen, and lungs of a congenitally syphilitic infant.

Hoffmann ${ }^{13}$ succeeded in infecting four monkeys (two macacis Rhesis and two cercopithecis) with syphilitic blood.

Babes and Panea ${ }^{50}$ found spirochætæ pallidæ in great numbers in the adrenals and liver of congenital syphilis. They suggest that they are like bacterial flagella and might be demonstrated by similar staining methods. They have found spermatozoa-like bodies in the blood of congenital syphilis.

Oppenheim and Sachs ${ }^{85}{ }^{86}$ succeeded in finding spirochæta pallida in 39 hard chancres and papules, failing in 21 . They also failed in nine buboes, 21 examinations of blood, 15 roseolar spots, two mucous plaques, seven gummata, and four cases of congenital syphilis. In 42 non syphilitic conditions they found $r_{0}$ spirochætæ pallidæ.

Bertarelli and Volpino ${ }^{88}$ found spirochæta pallida in 26 out of 42 primary and secondary cases. By the use of a silver 
solution method they demonstrated great numbers of spirochrta in sections of the liver of a congenitally syphilitic child and by control observations showed that they had not to do with elastic fibres, connective tissue fibrils, or nerveendings. Cultures of syphilitic blood were all negative.

Herxheimer and Löser ${ }^{46}$ describe the presence of granules in the spirochata pallida, possibly of the nature of blepharoblasts, also small free bodies with nucleus, protoplasm, and membrane, possibly representing a developmental stage. They think that appearances formerly described as vibratile membrane were simply artefacts. They confirm the presence of flagella.

Nicolas, Favre, and André contribute an important paper. They describe the staining methods which they find most suitable. Their positive results were 4 out of 16 hard chancres, 8 out of 17 mucous plaques, 1 out of 7 buboes, but not pure. Examination of two cases of syphilitic pemphigus and the blood in three cases was negative. They examined numerous non-syphilitic lesions without finding the spirochreta pallida. They indicate certain changes of aspect which this parasite may undergo in course of preparation. They state that Widal and Ravant have examined the cerebro-spinal luid of 15 syphilitics without finding spirochrta pallida. They are not altogether convinced that spirochætæ found in some other non-syphilitic lesions are not spirochætæ pallidæ.

Burnet 90 refers to the finding of spirillar forms in spirillosis of birds by Sacharoff in the Caucasus and by Marchoux and Salimbeni (1902) in Rio de Janiero ; in sheep by Laveran and Theiler in the Transvaal (1903); and in tick fever in man by Dutton (1905). He draws analogies between dourine (mal de Cadéras, maladie $d u$ coï $\sigma$ ) and syphilis, the former being due to a trypanosome which can penetrate a healthy mucosa-e.g., vulva of dog or rabbit. He has seen Schaudinn's photographs of the flagella of spirochrta pallida and is not convinced of the reality of the flagella. He agrees with Vuillemin and Schaudinn that the spirochæta pallida is not a true spirochæta and is better described under the new name of spironema pallidum. He describes ten different methods of staining.

Bandi and Simonelli ${ }^{91}{ }^{93}$ found spirochrta pallida in the blood from a roseolar spot and in three out of five secondary lesions.

Fanoni ${ }^{91}$ gives his results with original and new Giemsa and with Marino's blue. Three photographs of spirochrta pallida illustrate the article, of which No. $2(\times 1400)$ is good but Nos, 1 and 3 are very doubtful, particularly No. 3, which is apparently either a wavy piece of fibrin or a drawn-out nucleus.

Gordon ${ }^{96}$ failed to detect spirochæia pallida in the lumbar puncture fluid from cases of cerebro-spinal syphilis or tabes with a distinctly syphilitic history.

Paltauf 97 discusses the quesion of the bacterial or protozoal nature of spirochæta pallida.

Lipschütz ${ }^{\text {os }}$ discusses the whole question very ably, very carefully, and in detail. His paper merits close study. His conclusions, drawn from a survey of the literature, are distinctly good. He notes that the age of the lesion and even a short energetic course of mercury seem to have little influence on the demonstration of spirochreta pallida. Others ${ }^{110}$ state that they disappear during mercurial treatmert. In 33 out of 49 cases of primary and secondary syphilis he demonstrated spirochætæ pallidæ. In three typical gummata the result was negative. In 12 nonsyphilitic controls the results were negative.

$K$. Herxheimer ${ }^{ \pm 7}$ in a later paper gives his method of staining with a hot saturated solution of gentian violet after alcohol fixation. He describes the larger spirochæta as having a double contour, best seen in photographs taken against a dark background. He also describes three forms of granules which he thinks may have something to do with the developmental stages of the parasite-one group within the spirochrta, another attached to it, and the third group free. Little can be said with regard to these except to record the observation. He refers to rodlets and sausage-shaped bodies described by Wechselmann and Lö wenthal.

Richards and Hunt ${ }^{100}$ describe three varieties of spirochætæ found in syphilitic lesions, one thick, straight, or slightly curvel, another thick but spiral, and the third delicate and spiral, corresponding to spirochæta pallida. They found the last organism in three cases in blood from roseola and in one of these cases in films taken on each of ten successive days.

I have already referred to the earlier results attained by Metchnikơ and Roux. They have written further extremely important papers ${ }^{20} 2122$ describing the results of inoculation of syphilitic material into monkeys and the results of the search for spirochæt $x$ in the experimentally produced lesions. I canoot refer here to their successful inoculation of human material in different species of monkeys, to their discovery that only in chimpanzees could secondary lesions be developed, or to their experiments in reference to autoinfection, protective inoculation, and production of an antiserum. These are all detailed in the papers mentioned above, particularly the second. I can here refer only to their opinions and results so far as concerns the relation of the spirochrta pallida to syphilis. They point out that the tinctorial properties regarded by Schaudinn as differential for the spirochrta pallida are not of absolute constancy. They found in an experimental primary lesion in a macacus monkey a delicate pale spirochrta of typical aspect but staining clear blue with Giemsa. On inoculating material from this sore into a chimpanzee the lesion produced contained a spirochæta exactly like the former morphologically but staining a pale rose colour with Giemsa's agent taken from the same bottle. One can make too much of delicate "nuances" of colouration and other small details. In 31 experimental lesions in monkeys they found spirochrta corresponding to Schaudinn's organism 23 times : in eight out of ten chimpanzees, in four out of six cynocephali, and in 11 out of 15 macacus monkeys. No other organisms were found. They were never found in papules. Spirochæ' not found normally in monkey's skin. Incidentally it is noteworthy that these authors state that it is impossible to cultivate trypanosomes.

For other experiments on monkeys see Zabolotny, ${ }^{102}$ Schaudinn and Hoffmann, ${ }^{1+1}$ Siegel, ${ }^{2}{ }^{4}$ Neisser, ${ }^{103}$ Thibierge and Ravant, ${ }^{104}$ and Kraus and Prantschoff. ${ }^{50}$

Dalous ${ }^{101}$ refers to the history of the search for the cause of syphilis. He states that by the use of quartz lenses, with a magnification of from 2500 to 4000 diameters, an undulating membrane can be detected.

Bandi and Simonelli detail several methods of staining spirochæta pallida and describe a simple and rapid method they have elaborated. ${ }^{92}$ It somewhat resembles Jenner's method.

Pollio and Fontana ${ }^{105}$ found spirochæta pallida in eight out of 19 cases of primary and secondary syphilis. They failed altogether in tertiary syphilis, in other venereal ulcers, herpes progenita'is, acne vulgaris, folliculitis, and aphthous stomatitis.

Risso and Cipollina ${ }^{106}$ give details as to nine cases of primary and secondary syphilis. They were successful in demonstrating spirochætæ pallidæ in four out of five buboes and in two mucous plaques where they were few in numbers. They failed in films from circulating blood five times; blood from spleen, once; primary sore, twice ; and papule, once. One of the hard chancres was cicatrising and in the other several injections of mercury had been given. Examination of two gummata was negative.

Pascalis ${ }^{107}$ concludes that spirochæta pallida is demonstrable in all primary and secondary syphilitic lesions and never in non-syphilitic lesions.

Hübner ${ }^{48}$ refers to the history of the discovery and reviews the literature. The paper is interesting as indicating the countries to which the different writers belong and the dates on which they made their discoveries and communications also, and what is more important, he assigns to each man his share in adding to the knowledge of the subject. He thinks that the tertiary cases in which Rille found spirocbrta pallida were more likely very late secondary cases and that Vincent's bacillus fusiformis may be a developmental form of a spirochrta. He concludes that syphilis is a chronic spirillosis which is proauced by a spirochrta pathogenic not only for man but also for the old-world monkeys. He attempts to draw analogies between syphilis and recurrent fever, which is also a microbial disease pathogenic for man and also for monkeys. He compares the irido choroiditis which may occur in this fever with that occurring ia syphilis. Of course, the analogy breaks down when one considers, firstly, the chronicity of syphilis and the acuteness of rocurrent fever, and, secondly, the mononuclear leucocytosis of syphilis and the polynuclear leucocytosis of recurrent fever.

Veillon and Girard ${ }^{108}$ by Levaditi's method ${ }^{30}$ found spirochætæ in the roseolar rash. They suggest that the congestion is not toxæmic but the result of a veritable embolism of the terminal capillaries of the papillæ of the corium.

Moncorvo fils ${ }^{109}$ has found spirochætæ in congenital 
syphilis. He uses hydro-alcoholic solutions of saffranin and violet de dahlia.

Bodin ${ }^{110}$ in 37 cases found spirochæta pallida 21 times. $\mathrm{He}$ concludes that it is present constantly in untreated developing chancres; in secondary syphilides-papular, papulo-squamous, and ulcerated; and in ano-genital syphilides (condyloma). The organism disappears rapidly under the influence of mercurial treatment, whether general or local, and with local application of antiseptics (all observers do not agree on these points ${ }^{93}{ }^{88}$ ). He has never found spirocbæta pallida in tertiary lesions. He finds the spirochætæ in constant relation to red blood corpuscles. In conclusion, he thinks that their occurrence so constantly in the lesions cannot be considered merely a coincidence.

Buschke and Fischer ${ }^{17}$ have demonstrated clearly the spirochææa in sections by silver impregnation methods. This was first done by Bertarelli and Volpino. ${ }^{83}$ Levaditi modified the procedure according to the method of Ramon y Cajal and got similar results, but not only in the organs of a congenitally syphilitic infant but also in primary sores and secondary papules of an adult, and, in addition, in a primary sore in a monkey. Paschen demonstrated them by the same method and Buschke and Fischer also adopted it. The details of the method are given. Their successes included a condyloma latum, the liver and spleen in two congenital syphilitics, and the kidneys and cutaneous papules in another. The examination of the liver from a man with tertiary syphilis proved negative.

Taylor and Ballenger ${ }^{95}$ found spirochætæ pallidæ in two hard chancres and one mucous plaque. Neisser and Baermann ${ }^{103}$ had 27 positive and 12 negative results in man. In four out of 12 monkeys they had positive results.

$$
\text { (To be continued.) }
$$

\section{THE SPIROCHÆTA FOUND IN SYPHI- LITIC LESIONS.}

BY G. M. O. RICHARDS, M.R.C.S. ENG., L.R.C.P. LoND., SURGEON. R.N. ;

$$
\text { AND }
$$

LAWRENCE HUNT, M.R.C.S. ENG., L.R.C.P. LOND., SURGEON, R.N.

1. Description.-In The Laxcet of Sept. 30th, 1905 (p. 963), we described a spirillum as seen by us in films taken from syphilitic chancres to be of three varieties, and also stated that we had found the finest of these three varietie in blood films taken after the usual precautions of cleaning the skin with alcohol by puncturing the patient's skin through the site of a squamous syphilide. Having examined 200 cases of venereal sore and syphilitic lesions, we have come to the following conclusions in the description of the various spirilla: that in true syphilitic chancres there are to be found (1) straight or slightly bent rods in large numbers; (2) undulating organisms very similar to the first except for their attempts to coil ; (3) long delicate wavy spiral organisms, sometimes of great length, exactly similar to the spirochæta Obermeieri ; (4) organisms similar to the last, but finer as regards thickness and (5) lastly, the spirochæta pallida, which is characterised by its straightness and corkscrew form, the turns varying from ten to 30 with pointed ends and immeasurably fine. It is meant to draw a distinction between spiral and corkscrew ; the former appear curved on the $\mathrm{fl} t \mathrm{t}$ in the same plane, while the latter have turns occupying different levels.

Since the examination of fluid from a syphilitic lesion in a banging drop we can now account for the first three forms, which are the same organism at different stages of its existence, and is the spirockæta refringens, and so named by Schaudinn and Hoffmann. This organism is a highly refractile body, motile, but when resting appearing as a straight rod and when moving assuming a spiral form. The movements are of two kinds-one consisting of a contraction of the organism starting from the centre and gradually drawing in the spirals, which is followed by a relaxation of these spirals, the organism becoming a straight rod again; the other one of locomotion, and as far as could be ascertained the organism did not move very far. Sometimes they were seen anchored by one end to a leucocyte, the free end swaying to and fro.

The spirochrta pallida we have been unable to see in the hanging drop. The varieties of form seen in a film from a syphilitic chancre are thus probably accounted for by the state of rest or activity in which the organism existed at the moment the film was made. The fourth variety mentioned above appears to be an intermediate stage between spirochæta refringens and spirochæta pallida, and in films from syphilitic chancre it is often difficult to draw the line between the very spiral refringens and the corkscrew pallida.

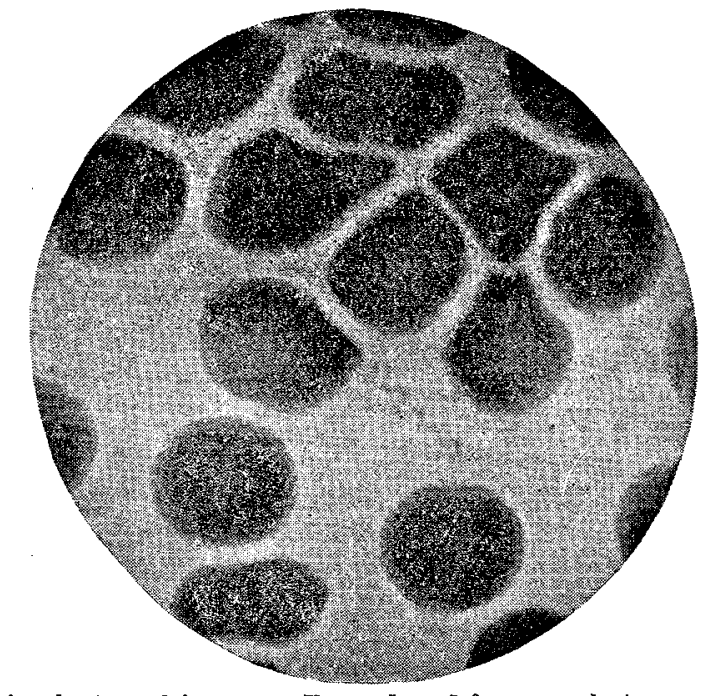

Spirochæta refringens. Reproduced from a photograph by Dr. H. R. D. Spitta. $\times 1750$.

In an article by McWeeney, ${ }^{1}$ which was the first notice in English of these organisms, is an illustration showing spirochætæ from a syphilitic lesion none of which resemble the spiroct reta pallida as observed by us, and we should describe all of them as spirock rta refingens, as their spirals are all far too separate and not corkscrew. In the American Journal of the Medical Sciences of Jan, 19th, 19C6, is a figure that illustrates fairly well the difference between the spirochæta refringens and the spirochæta pallida except that the pallida has not sufficient curls. In the New Yor? and Philadelphia Mrdical Journal of Nov. 4th, 1905, is an article by Fanoni, illustrated by micro-photographs of the spirochæeta pallida, which, however, do not correspond to our idea of that organism and we look upon them as being examples of the refringens. In the Australasian Medical Gazette, in an article by Munro, are two micro-photographs of spirochætæ showing the pointed ends.

2. Staining.-Up to the present we have found that Giemsa's modification of Romanowsky's stain gives the best results and always use it. The stain should be diluted with distilled water 1 in 3 in a watch-glass and pipetted on to the film, previously fixed for ten minutes in alcohol. Application of the stain for five minutes is sufficient, though the most certain results are obtained in 15 minutes. Apparently Canada balsam and cedarwood oil do not bleach the stained organism as some observers have suggested, and specimens now six months old appear as deeply stained as when first prepared. Leishman's stain acts well but is not so intense as Giemsa's. The organism stains with carbolfuchsin, but the fine varieties cannot possibly be distinguished owing to the general intense staining in a scraping from a sore. Some observers have stated that this stain is the best, but we firmly believe they have no idea of what spirochæta pallida is really like. Carbol-thionin stains spirochæta refringens well but we have not detected spirochæta pallida by this method. Generally the spirochæta refringens stains easily and well but spirochæta pallida stains only very slightly, as does the fourth variety. We intend to try Levaditi's silver nitrate method.

3. Situations in which found.-All forms are found in the primary lesion but spirochæta refringens is here marked by its numbers in the superficial discharge, while spirochæta pallida is rarely found unless the lesion is actually scraped. In condylomata and mucous tubercles all forms are seen but again spirochæta pallida is chiefly found by expressing serum from the lesion, in which serum it occurs more abundantly than the refringens. The shotty inguinal glands of the early secondary stage when punctured with a hypodermic needle under strict aseptic conditions supply the best examples of spirochæta pallida, and up to the present we have found no form of spirochæta refringens in this position. In the skin, 